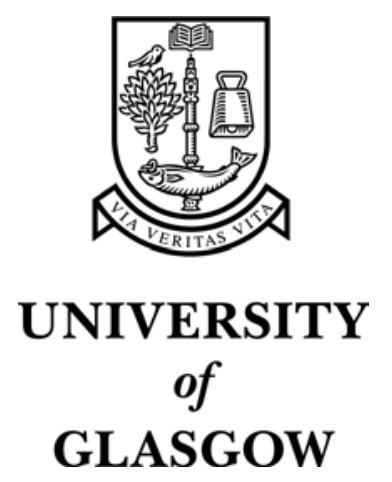

Beattie, V. and McInnes, W. and Fearnley, S. (2004) A methodology for analysing and evaluating narratives in annual reports: a comprehensive descriptive profile and metrics for disclosure quality attributes. Accounting Forum 28(3):205-236

http://eprints.gla.ac.uk/archive/00000407/ 


\title{
A Methodology for Analysing and Evaluating Narratives in Annual Reports: A Comprehensive Descriptive Profile and Metrics for Disclosure Quality Attributes
}

\author{
Vivien Beattie*, Bill McInnes** and Stella Fearnley***
}

* University of Glasgow

** University of Stirling

*** University of Portsmouth

Draft 3: June 2004

Correspondence details:

Professor Vivien Beattie (corresponding author)

Department of Accounting and Finance

University of Glasgow

65-73 Southpark Avenue

Glasgow

G12 8LE

Tel. 01413306855 (direct line) 5666 (department)

Email V.Beattie@,accfin.gla.ac.uk

Acknowledgments:

We would like to thank the P D Leake trust (a charity associated with the Centre for Business Performance of the Institute of Chartered Accountants in England and Wales) for funding this project on stakeholder reporting and user needs. The present 
paper forms part of the first stage of this project, which is to document company practices. 


\title{
A Methodology for Analysing and Evaluating Narratives in Annual Reports: A Comprehensive Descriptive Profile and Metrics for Disclosure Quality Attributes
}

\begin{abstract}
There is a consensus that the business reporting model needs to expand to serve the changing information needs of the market and provide the information required for enhanced corporate transparency and accountability. Worldwide, regulators view narrative disclosures as the key to achieving the desired step-change in the quality of corporate reporting. In recent years, accounting researchers have increasingly focused their efforts on investigating disclosure and it is now recognised that there is an urgent need to develop disclosure metrics to facilitate research into voluntary disclosure and quality (Core, 2001). This paper responds to this call and contributes in two principal ways. First, the paper introduces to the academic literature a comprehensive fourdimensional framework for the holistic content analysis of accounting narratives and presents a computer-assisted methodology for implementing this framework. This procedure provides a rich descriptive profile of a company's narrative disclosures based on the coding of topic and three type attributes. Second, the paper explores the complex concept of quality, and the problematic nature of quality measurement. It makes a preliminary attempt to identify some of the attributes of quality (such as relative amount of disclosure and topic spread), suggests observable proxies for these and offers a tentative summary measure of disclosure quality.
\end{abstract}

Keywords: business reporting; disclosure; disclosure quality; narratives; annual reports; content analysis; forward-looking information; non-financial information; qualitative information 


\section{A Methodology for Analysing and Evaluating Narratives in Annual Reports: A Comprehensive Descriptive Profile and Metrics for Disclosure Quality Attributes}

INTRODUCTION

In recent years, the nature of business has changed fundamentally. Competitive advantage increasingly involves value creation processes that rely on intangible assets not recognised in the financial statements. To serve the information needs of the market and provide the information required for corporate transparency and accountability, there is now a consensus that the business reporting model needs to expand beyond the traditional financial reporting model that emphasises backwardlooking, quantified, financial information (e.g., Elliott, 1992; AICPA, 1994; Wallman, 1995, 1996, 1997; ICAS, 1999; Lev and Zarowin, 1999; Lev, 2001; FASB 2001a; and ICAEW, 2003). ${ }^{1}$ The general thrust of these articles and reports is that there is a need for more information that is forward-looking and non-financial in nature. It is recognised that much of this new information will be 'soft', i.e., either unquantified or unquantifiable.

Of particular note is the report published by the AICPA (1994), which has become extremely influential (the Jenkins Report). This set out to improve business reporting by adopting a customer focus, i.e., by meeting the information needs of investors and creditors. The report proposed a comprehensive model of business reporting that embraced a 'broader, integrated range of information' (p.131). This model comprised eight main topics (financial data, operating data, management analysis, forwardlooking information, information about management and shareholders, objectives and strategy, description of business and industry structure) and many sub-topics. In response to the report, FASB set up a Business Reporting Research Project to consider the types of information that companies are voluntarily providing and the means for delivering it. Reporting on the first of these two issues, FASB stated that 'the importance of voluntary disclosures is expected to increase in the future because of the fast pace of change in the business environment' (2001b, p.v).

Worldwide, narrative communication in annual reports is viewed as the crucial element in achieving the desired step-change in the quality of corporate reporting and

\footnotetext{
${ }^{1}$ The recent wave of accounting scandals has provided further impetus to the drive for enhanced transparency and accountability.
} 
regulators are focussing attention on the management discussion and analysis statement in the annual report (referred to as the MD\&A in most countries and the Operating and Financial Review (OFR) in the UK). ${ }^{2}$ In some jurisdictions, guidelines are being extended and revised, while in others disclosures are becoming mandatory. In the US, post-Enron, MD\&A regulations are being strengthened (e.g., SEC, 2003). In Canada, the Canadian Institute of Chartered Accountants (CICA) issued more detailed MD\&A guidelines that sets out six disclosure principles and develops a fivepart integrated disclosure framework that covers strategy, key performance drivers, capabilities, results and risks (CICA, 2002). In the UK, the Accounting Standards Board issued revised OFR guidance which draws upon the Jenkins framework (ASB, 2003). Company law reviews in both Australia and the UK are proposing mandatory OFRs for listed companies (G100, 2003; DTI, 2002). Draft regulations were recently issued in the UK (DTI, 2004). Finally, consideration of MD\&A statements was put on the IASB agenda in 2002.

Meanwhile, accounting researchers have increasingly focused their efforts on investigating disclosure, in particular the determinants of disclosure and the capital market consequences (for a recent review of the empirical disclosure literature, see Healy and Palepu, 2001). Healy and Palepu observe that 'one of the limitations of the [studies on voluntary disclosure] is the difficulty in measuring the extent of voluntary disclosure' (2001, p.32), while Core notes that 'improved measures of disclosure quality also need to be developed' (2001, p.16). To date, two principal ways of measuring disclosure have been employed. The first approach has been to use subjective analyst disclosure quality rankings. Although this approach is not without conceptual problems, a real practical problem for US researchers is that the AIMR discontinued its rankings in 1997 (after ranking fiscal year 1995). Many other countries have never had similar rankings available. The second approach, which has a long history, has been to use researcher-constructed disclosure indices where the amount of disclosure is used as a proxy for disclosure quality (e.g., Botosan, 1997; Lang and Lundholm, 2000).

Given the limitations and weaknesses of these two approaches, there is clearly a pressing need for research effort to be devoted to developing new ways of

\footnotetext{
${ }^{2}$ Corporate communication is now an established interdisciplinary field (van Riel, 1997).
} 
documenting disclosure practices, identifying dimensions of disclosure quality and exploring possible measurement metric proxies. It is suggested that developments of this nature have two main advantages. First, the development of a comprehensive disclosure profile serves as a practical tool, permitting the benchmarking of current practices. This allows inter-company, inter-industry and inter-country comparisons to be made and also allows changes over time to be monitored. Second, a richer set of objective measures relating to disclosures can permit much more powerful tests of many research questions that relate to narrative disclosures.

To this end, the present paper has two main objectives. First, the paper introduces to the academic literature a methodology for generating a rich descriptive profile of a company's narrative disclosures. The basis of this profile is a comprehensive fourdimensional framework for the holistic content analysis of narratives, based on the coding of topic and three type attributes. The topic analysis is based on The Jenkins Report (AICPA, 1994), which proposes a 'comprehensive model of business reporting'. The type analysis captures the time orientation, financial/non-financial and quantitative/qualitative attributes of each text unit. A text unit is defined as a phrase containing a single piece of information. Associated with this framework is a detailed set of coding procedures and a computer-assisted methodology for implemention. Second, the paper discusses the complex concept of quality and the problematic nature of quality measurement. It makes a preliminary attempt to identify some of the attributes of quality, suggests observable proxies for these and offers a tentative summary measure of disclosure quality.

The remainder of this paper is structured as follows. Section two describes and critiques the different extant approaches to the study of narratives in annual reports. Section three outlines the general principles of content analysis. Section four explains the new computer-assisted methodology that generates a comprehensive descriptive disclosure profile of annual report narratives. Section five presents an illustrative application of the procedure to the narratives in Cadbury Schweppes' 1999 annual report. The concept of quality is explored in section six and proposals are made regarding possible attributes of quality, observable proxies for some of these and aggregation into a summary measure of disclosure quality. The final section summarises and concludes. 


\section{EXTANT APPROACHES TO THE ANALYSIS OF NARRATIVES IN ANNUAL REPORTS}

The extant literature adopts a variety of approaches to the analysis of narratives in annual reports. These are summarised in Figure 1. ${ }^{3}$ Although what is being measured varies across approaches, the implicit underlying construct of interest is generally the 'quality' of disclosure. The major distinction to be made is that between subjective analysts' ratings and semi-objective approaches. Of the semi-objective approaches, some specify ex ante a list of items and scrutinise the text for their presence, ignoring sections of the text that do not relate to this list. This is the approach taken by the large body of disclosure index studies and it is characterised in this paper as a partial type of content analysis. It is a fairly objective, form-oriented content analytic method. ${ }^{4}$ Other approaches encompass all of the text (textual analyses). These include thematic, meaning-oriented content analysis (where the whole text is analysed), readability studies and linguistic analysis. Each of these five approaches is discussed below in turn.

[Figure 1 about here]

\section{Subjective ratings}

In the US, many studies make use of analyst scores of disclosure quality provided by the Association of Investment Management and Research (AIMR) (formerly the Financial Analysts Federation (FAF)). ${ }^{5}$ These reports provide an overall measure of corporate communications with investors. Typically, each year an average of 27 industries are covered, with an average of 17 companies being evaluated by 13 analysts in each industry. There are separate ratings for annual published information; quarterly and other published information; and investor relations. Unfortunately, the

\footnotetext{
${ }^{3}$ Beattie, McInnes and Fearnley (2001, pp.4-5) provide a broader review of the areas of research that relate to accounting narratives.

${ }^{4}$ An element of subjectivity is introduced in the identification of keywords and the assignment of words to common semantic units (Smith and Taffler, 2000, p.638).

${ }^{5}$ Studies that use the AIMR rankings include Imhoff (1992), Lang and Lundholm (1993; 1996), Welker (1995), Sengupta (1998), Healy, Hutton and Palepu (1999), Bushee and Noe (2000), Botosan and Plumlee (2002), Gelb and Zarowin (2002), Lundholm and Myers (2002) and Byard and Shaw (2003).
} 
AIMR discontinued its disclosure rankings in 1997 (after ranking fiscal year 1995) and other countries (such as the UK) do not have similar rankings.

Lang and Lundholm (1993) assume that the ratings measure 'disclosure informativeness' (footnote 1). They acknowledge that 'a disadvantage of the FAF data is that they are based on analysts' perceptions of disclosure rather than direct measures of actual disclosure' (p.247). Healy and Palepu criticise these ranking on three grounds: the lack of clarity as to whether the analysts on the panels take the ratings seriously, the unclear basis on which firms are selected for inclusion, and the potential biases that analysts bring to the ratings (2001, p.34).

In other countries, publicly available ratings are not routinely available and so researchers have had to approach analysts directly (e.g., Clarkson, Kao and Richardson, 1999). A variant on the use of analyst ratings is the use of SEC ratings of MD\&A compliance, a measure is used by Barron, Kile and O'Keefe (1999).

\section{Disclosure index studies}

Because of the difficulty of assessing disclosure quality directly, disclosure index studies assume that the amount of disclosure on specified topics proxies for the quality of disclosure. Often, a simple binary coding scheme is used, whereby the presence or absence of an item is recorded. Other coding schemes incorporate ordinal measures (frequently three levels), to allow for the 'quality' of the specific disclosure to be assessed (e.g., is the disclosure on topic $\mathrm{X}$ merely qualitative or is it quantified?). Quantified disclosure scores 2, qualitative disclosure scores 1 while no disclosure scores 0. This is the approach adopted by Botosan (1997), who observes that 'disclosure quality is also important but very difficult to assess. As a result, researchers tend to assume quantity and quality are positively related.'

Marston and Shrives (1991) provide an excellent (although now somewhat dated) review of the use of disclosure indices in accounting research, particularly in company annual report and accounts. In this setting, a fundamental distinction that is often made is between mandatory and voluntary disclosure. Where a measure of the extent of general disclosure is sought, the selection of items involves the explicit or implicit specification of a user group, as the interests of user groups vary. Weightings are 
typically achieved by conducting attitude surveys among relevant user groups, asking about the importance of each item, although it has been found that the weighted and unweighted scores tend to give the same results where there is a large number of items. Scoring can take several forms, most commonly either a nominal score to indicate the presence/absence of the item or an ordinal level score to capture the degree of specificity of the item (an extension of the weighting system). ${ }^{6}$ The importance of clear instructions to achieving satisfactory levels of reliability is emphasised by Marston and Shrives (1991) and the failure of many studies to explicitly consider reliability and validity issues is commented upon. Marston and Shrives also emphasise that the index score 'can give a measure of the extent of disclosure but not necessarily the quality of disclosure' (p.195, emphasis added). They conclude that, while the construction of disclosure indices inevitably involves subjective judgment, it has proved to be a valuable research tool that will continue to be used as long as company disclosure is a focus of research.

Because the number of items that could be disclosed by a company is very large, researchers have tended to focus on a small sub-set of items (e.g., social and environmental disclosures; mandatory disclosures). Most disclosure index studies focus either on inter-company differences or inter-country differences. In a few cases, longitudinal analyses have been undertaken (e.g., Camfferman, 1997; Schleicher, 1998). For practical reasons, few studies adopt wide-ranging measures of general disclosure. Those broadly-based index studies that draw in some way upon the Jenkins Report, and so are of particular relevance to the present study, are now considered in detail.

In a widely cited study, Botosan (1997) constructs her own index to measure the voluntary disclosure level in 122 companies in the machinery industry. ${ }^{7}$ The selection of items included in the index was guided, principally, by recommendations provided in the Jenkins Report (AICPA, 1994), the SRI International (1987) survey of investor information needs and the Canadian Institute of Chartered Accountants (1991) study of the annual report. There were five categories of information: background

\footnotetext{
${ }^{6}$ For a more detailed discussion of scoring see Boyatzis (1998, pp.130-134).

${ }^{7}$ She focuses on the annual report disclosures because annual report disclosure levels are correlated positively with the amount of disclosure provided via other media and it is considered by users to be one of the most important sources of corporate information (pp.329-331).
} 
information; summary of historical results; key non-financial statistics; projected information; and management discussion and analysis. The index comprised 35 major elements spread across these categories. Additional points were awarded for quantified information. Multi-segment firms were required to disclose information either for all segments or for the combined entity to earn all of the points.

Robb, Single and Zarzeski (2001) undertake a topic-based analysis of non-financial disclosures, as recommended by the Jenkins Report, in Australia, Canada and the US. They define non-financial disclosure as 'qualitative information included in company annual reports, but outside of the four financial statements and related footnotes'. The categories used in their disclosure scoring sheet are based upon the list of nonfinancial information items desired by users included in the database of materials used by the Jenkins Committee. These items were grouped into six categories, three forward-looking topics (environment around the company; strategy and management; and company trends) and three historical topics (environment of the company; production; and customers). A total of 65 items were included. For each item, a score of 1 (no disclosure), 2 (some disclosure) or 3 (extensive disclosure) was awarded. These scores were aggregated to form an overall disclosure score. They find differences in disclosure levels for particular non-financial information categories, explained by firm size, industry classification, degree of geographic dispersion and country of domicile. This methodology is used by Vanstraelen, Zarzeski and Robb (2003) to investigate a further three countries (Belgium, Germany and the Netherlands), with larger, global companies being found to provide higher levels of non-financial disclosure.

\section{Thematic content analysis}

Jones and Shoemaker (1994) review studies concerning the content of accounting narratives. ${ }^{8}$ Thirty-six thematic studies are reviewed, eighteen of which concern the corporate annual report (either the entire narrative content or restricted to specific sections of the annual report, such as the chairman's statement or the MDA/OFR).

\footnotetext{
${ }^{8}$ They define content analysis to include both studies that code text into groups and readability studies that objectively measure readability. These two types are described as thematic and syntactic studies, respectively. In the present paper, the term content analysis is restricted to the former type of study, following Weber's (1985) use of the term.
} 
They note that the recording unit for most studies is 'themes' (which may be longer or shorter than a sentence), with words being the next most common unit used.

Although not strictly a content-analytic study, FASB (2001b) does undertake a detailed review of the entire content of voluntary disclosures in annual reports, examining the public disclosures of six to nine large companies in eight industries. The FASB report makes no attempt to quantify the amount or nature of disclosures in these topic categories; rather it provides, for each industry, detailed lists of examples of disclosures considered to be useful and to represent good practice. Their overall conclusion is that there is considerable scope for enhancing disclosures relating to critical success factors and trends surrounding those factors, forward-looking information, intangibles, bad news and metrics used by companies to manage their operations (pp. $v$-vi).

Rutherford (2002) conducts a detailed line-by-line coding of the OFR of 10 listed UK companies, based on the topic categories in the original ASB guidance (ASB, 1993). Just over half of all disclosures are found to relate to either operating results for the period $(38 \%)$ or investment for the future $(13 \%)$.

\section{Readability studies}

Jones and Shoemaker (1994) review 32 readability studies (26 of which address annual report narratives). These studies are designed to quantify the cognitive difficulty of text and generally use a readability formula such as the Flesch index. ${ }^{9}$ The computed score is compared to external benchmarks to evaluate the degree of difficulty of the text. There is general consensus that annual report narratives are difficult or very difficult to read. Despite their objectivity and reliability, there are recognised to be many problems associated with the application of readability scores to accounting narratives. First, it is argued that measures designed for children's writings may well be inappropriate for adult, technical writings. Second, readability scores focus on word and sentence-level features and ignore aspects of the text as a whole. Finally, they take no account of the interests and motivations of the reader.

\footnotetext{
${ }^{9}$ This index is based on a combination of sentence length and word syllable count.
} 


\section{Linguistic analysis}

Sydserff and Weetman (1999) make a valuable contribution to research into annual report narratives by introducing a new method for their evaluation - the texture index. Although they characterise their method as an alternative to readability formulas, the texture index captures a much richer set of text characteristics and is shown not to be associated with readability scores and indeed it. Sydserff and Weetman (1999) draw upon theoretical and applied linguistics to develop a text-focused method of scoring narratives and show how this method can be adapted to apply to accounting narratives, in particular the OFR. Their method is explicitly grounded in the linguistic theory of narrative communication developed by de Beaugrande and Dressler (1981) and the texture index developed from this by Roseberry (1995), an applied linguist.

De Beaugrande and Dressler (1981) identify seven principles that determine the communicative effectiveness of narratives, some of which are text-centred and some of which are user-centred. Roseberry (1995) uses this to develop six criteria for evaluating narratives, which are termed indexicals. Each text unit (defined as one independent clause with all subordinate clauses attached to it) is scored for each indexical as 0,1 , or 2 , with 0 indicating the absence of a particular characteristic of texture and 1 and 2 indicating defined degrees of its existence. His method was validated with reference to the views of expert judges.

Sydserff and Weetman (1999) draw upon both studies to select six indexicals, which describe attributes of the narrative (topicality, intertextuality, conjunction, connectivity, information category shift and specificity). ${ }^{10}$ They develop detailed rules for the classification of text-units and apply them to short extracts (average of 39 text-units) from ten UK FTSE-100 companies' OFRs. Although the individual indexical scores are arithmetically summed to provide an overall texture score, the authors caution against assuming that the higher the texture score the better, given the low correlation observed between indexicals. A sub-analysis of the topicality index reveals that only 24 out of 392 text-units $(6.1 \%)$ were concerned with forward-looking information (i.e., main topic A). ${ }^{11}$ One of the advantages of their method is that it provides a unit-by-unit analysis of the narrative, allowing the researcher to capture

\footnotetext{
${ }^{10}$ For a detailed description, see Sydserff and Weetman (1999, pp.465-472).

${ }^{11}$ These figures are derived from Sydserff and Weetman, 1999, Tables II and VII.
} 
variability in the narrative (Courtis, 1998, p.469). They suggest that further research is required to provide user weightings for each text characteristic.

\section{Discussion}

The present paper argues that, with the notable exception of Sydserff and Weetman (1999), extant approaches to the analysis of accounting narratives in annual reports suffer from two fundamental limitations. First, they are essentially one-dimensional, whereas disclosure is a complex, multi-faceted concept. The focus is generally on classifying the topic to which the information item refers and often only the presence or absence of a disclosure on a given topic is captured. In general, little consideration is given to the type of disclosure made in relation to that topic. Yet it is becoming clear from the debate on the future of business reporting that certain dimensions relating to type are of critical relevance. Beattie (2000) reviews this debate and suggests a framework for classifying and describing information items. The first dimension to be considered is topic, with specific information items being nested within broad themes or categories in a hierarchical structure. In addition to this, each item of information has three type attributes, based upon the following dichotomous descriptors: historical/forward-looking; financial/non-financial; and quantitative/nonquantitative.

The second limitation is that many extant approaches are partial, either because they examine only selected sections of the annual report narrative or because they focus on particular issues or pre-selected index items. To the best of our knowledge no-one has undertaken a detailed analysis of the entire narrative content of corporate annual reports.

\section{CONTENT ANALYSIS}

Disclosure index studies are based on the general principles of content (or thematic) analysis - a well-established method in the social sciences. Good general discussions of the method are provided by Holsti (1969), Krippendorff (1980), Weber (1985) and Boyatzis (1998). Content analysis involves classifying text units into categories. For valid inferences to be drawn, it is important that the classification procedure be reliable (i.e., different people code the text in the same way) and valid (i.e., the variables generated from the classification procedure represent what the researcher 
intended it to represent) (Weber, 1985, p.12). Content analysis can be computer-aided or human-coded, with the latter having the advantage that it permits the quantitative assessment of achieved reliability. Following coding, the form of analysis and interpretation that is undertaken can vary along a continuum from purely qualitative and verbally descriptive methods to primarily quantitative methods that permit statistical analysis. The use of quantitative methods requires that the units of coding be scored in some way (Boyatzis, 1998, ch.6). The researcher can then aggregate the counts in various categories to form a measure of "the intensity of concern with each category' (Weber, 1985, p.39).

Three types of reliability can be identified: stability (the extent to which the same coder is consistent over time when coding the same content); reproducibility or intercoder reliability (the extent to which different coders produce the same results when coding the same content); and accuracy (the extent to which the classification of text corresponds to a standard or norm) (Krippendorff, 1980, pp.130-2). Since stability is a weak measure of reliability and standard codings seldom exist, the most frequently reported measure is inter-rater reliability.

Milne and Adler (1999) provide a very thorough exploration of reliability in content analysis, including a thorough review of formal reliability analysis and its complexities, focusing on reproducibility. The simplest measure of reliability is the coefficient of agreement, which is the ratio of the number of pairwise interjudge agreements to the total number of pairwise judgments. However, this measure takes no account of the likelihood of random agreement, which increases inversely with the number of coding categories. An alternative measure of reliability that attempts to adjust for chance is Scott's $\mathrm{pi}^{12}$, which is defined by Krippendorff, (1980, p.138) as:

$$
\text { Scott's pi }=1-\frac{100-\% \text { of observed matches }}{100-\% \text { of expected matches }}
$$

\footnotetext{
${ }^{12}$ Other measures are: Krippendorff's alpha, Cohen's kappa and Leigh's lambda (see Milne and Adler (1999) and references therein).
} 
Researchers have tended to focus on construct validity, which is the extent to which the measure is correlated with other measures of the same construct. ${ }^{13}$

Both Weber (1985) and Boyatzis (1998) provide useful discussions regarding how to develop and test a coding scheme. The basic steps are:

1. define the recording unit (e.g., word, sentence, theme);

2. define the categories (this involves several key choices to be made, such as whether the categories will be mutually exclusive or not; hierarchical or not; single versus multiple classification; how narrow or broad; use of categories (comprising groups of words with similar meanings) or themes (comprising groups of words with different meanings that taken together refer to some theme or issue));

3. test coding of a sample of text (use abbreviated tags for categories);

4. assess reliability;

5. revise coding rules (e.g., develop disambiguation rules);

6. repeat steps 3 to 5 until reliability is satisfactory;

7. code all text; and

8. assess achieved reliability (Weber, 1985, pp. 23-24).

\section{DEVELOPING A HOLISTIC COMPUTER-ASSISTED DISCLOSURE PROFILE}

The methodology outlined in this section, developed by Beattie, McInnes and Fearnley $(2001,2002 a, b)$, has not yet been introduced to the academic journal literature. The methodology overcomes the limitations of the extant approaches described above in that it is multi-dimensional rather than one-dimensional and it is aimed at analysing all of the narrative sections in companies' annual reports. The methodology is based on the general principles of content analysis outlined in the previous section.

\footnotetext{
${ }^{13}$ There are four other types of validity. Internal face validity (the weakest type) refers to the correspondence between the investigators' definition of a concept and the category that measures it. Other measures of external validity relate the content-analytic data to an external criterion. Hypothesis validity is the correspondence between variables produced by content analysis and theory. Predictive validity is the extent to which predictions based on content analysis have predictive power. Finally, semantic validity is the extent to which text units placed in the same category are agreed to have similar meanings or connotations (Weber, 1985, pp.16-21).
} 


\section{Narrative material analysed}

The narratives to be analysed are those voluntary disclosures contained in the company annual report and accounts. The only sections excluded, in addition to the audited financial statements and notes, were sections heavily subject to regulatory requirements or otherwise fairly standard in nature: the auditor's report, the directors' report, corporate governance statements, directors' remuneration reports, tables of contents, information for shareholders, historical summary tables and lists of principal operating companies. The material remaining therefore includes highlights, chairman's statement, CEO's review, OFR, people, community, directors and advisors and captions from pictorial material. In some cases, this material was spread across more than one document.

\section{Computer software}

The computer software package used is QSR NUD*IST, a commercial computer package designed to assist in the analysis of non-numerical and unstructured data, by supporting the processes of coding data, searching text and searching patterns of coding (QSR, 1997). Coding takes place via the index system, which is made up of nodes (i.e., coding categories) and which can either be unstructured (free nodes) or organised into a hierarchical index tree. The index system was introduced into NUD*IST using the 'build-tree' command.

\section{Preparing the text for coding}

The text to be included was scanned from the hard copy annual report (the OCR software allows specific regions on the page to be selected) and saved as a text file. The output from the scanning was checked for accuracy and edited as necessary. Text files were then prepared for input to the QSR NUD*IST software. This involved several steps: setting all text to a standard Courier font and standard line spacing; removing all formatting such as bold and italics; changing all main section headings (as listed in the table of contents) to uppercase and flagging as sub-headers (by inserting a leading asterisk); starting each sentence on a separate line; and adding a wide right hand margin (see Gahen and Hannibal, 1998, ch.4). Each company text file (document) was then input to NUD*IST. 


\section{Developing the coding instrument}

The four dimensional content analysis framework was developed by two of the authors of this paper over a period of 12 months and many test rounds into a detailed and robust set of categories and coding rules, following the steps recommended by Weber (1985) and Boyatzis (1998). Text was independently coded, differences discussed, and the coding instrument revised and extended until there was believed to be a sufficient convergence of views. In the case of two dimensions (time orientation and quantitative/non-quantitative), the simple dichotomous categories initially envisaged required some refinement. In addition, the definitions for the topic classifications, which were drawn from the Jenkins Report (AICPA, 1994), had to be somewhat relaxed in order to accommodate many actual disclosures and a few extra categories were added. The complete architecture of the coding scheme is presented in Figure 2.

[Figure 2 about here]

To reflect this coding scheme in NUD*IST, there are four free nodes, each with its own hierarchy. For example, node (4 111 ) represents the topic dimension; level one category (i.e., main topic): financial information; level 2 category (i.e., sub-topic): sales. Similarly, node ( $\left.\begin{array}{lll}3 & 1 & 2\end{array}\right)$ represents the quantitative/non-quantitative dimension; level one category: quantitative; level two category: change.

The four dimensions of the coding scheme in large part determined the appropriate semantic unit (recording unit). The sentence proved to be too large a unit and was split as necessary into multiple units so that each text unit represented a single 'piece of information' that was meaningful in its own right, given the context in which it was presented. It was often the case that the process of coding to one or more of the four dimensions pointed to the appropriate split(s). Thus, a split was introduced if it was required to accommodate at least one of the four dimensions. These splits are obviously cumulative, although the splits required for different dimensions often coincide. An illustrative example is provided in Figure 3.

[Figure 3 about here] 
During the development of the coding instrument, flags, qualifications and exclusions, and examples were added to the coding instrument. The decision was taken early on to allow only one code for each dimension, so that percentages would sum to $100 \%$. In some cases, topic codes are not fully mutually exclusive and two general principles were applied to resolve this problem of competing topic codes. The first takes account of the fact that some main topic codes are of particular interest because they seem to signal information of particular value, i.e., management analysis (MA), business objectives and strategy (BOS), and forward-looking information (FL). We reasoned that these codes should dominate other codes. Thus, if a text unit could be coded to, say, either financial data (FIN) or MA, the dominance principle was applied. Where this principle was unable to resolve the conflict, the second general principle applied was that units were coded to the more specific code (the specificity principle).

Over many iterations, a detailed, 24-page coding instrument was developed that included, for each category in each dimension, ${ }^{14}$ the following elements:

1. a label, comprising category name and code;

2. a definition of what the category concerns;

3. a description of how to know when the category occurs (i.e., how to 'flag' the category);

4. a description of any qualification or exclusions to the identification of the category; and

5. examples, both positive and negative, to eliminate possible confusion when looking for a category.

These are the five elements that Boyatzis (1998) recommends to achieve a 'good' code (i.e., one with the maximum probability of producing high inter-rater reliability and validity). An extract from the coding instrument is provided in Figure 4.

[Figure 4 about here]

The coding process

The process of coding comprised five stages:

\footnotetext{
${ }^{14}$ This involves 3 categories for time orientation, 2 for financial/non-financial, 6 for quantitative/nonquantitative and 79 topic categories.
} 
1. The scanned document, initially split into sentences as text units, was imported into NUD*IST and a print-out of the document (with text-units numbered) obtained.

2. Initial coding was undertaken, off-screen. This involved the identification of additional text unit splits and the coding of each text unit in terms of each of the four dimensions. Each text unit was given a four-part code of the form H/F/NQ-FAC/FIN-SAL. ${ }^{15}$ The only exceptions to this were subheaders (section headings) and sub-sub-headers (headings within sections) which were coded to free nodes outside the index tree.

3. Coding was transferred to NUD*IST, i.e., sentence splits were incorporated and coding added based on the index system. ${ }^{16,17}$

4. A node-report was obtained from NUD*IST showing references with text. This lists all text units assigned to each category.

5. The node-report was checked (errors tending to stand out clearly when set against a group of text units that are all in the same category). Amendments were made as necessary.

\section{Reliability and validity assessment}

Five blocks of text, each five sentences in length, were selected from the narrative text of both the largest and smallest companies in the sample, the blocks being spread evenly throughout the text. These were independently coded by two of the authors. The level of agreement on the within-sentence text splits was $84 \%$. The coefficient of agreement on the coding averaged $86 \%$ across the four dimensions. The values for the individual dimensions were: $71 \%$ at the sub-topic level and $88 \%$ at the main topic level; $86 \%$ for the time dimension; $97 \%$ for the financial/non-financial dimension; and $92 \%$ for the quantitative/non-quantitative dimension. Scott's pi was $70 \%$ at the subtopic level and $84 \%$ at the main topic level. The cut-off level for acceptability ranges from 70\% (Boyatzis, 1998, p.156) to 80\% (Guthrie and Matthews, 1985, p.261). Thus, the levels of reliability attained were generally highly satisfactory.

\footnotetext{
${ }^{15}$ It is recognised that the four dimensions are not always statistically independent. For example, time orientation can be an indicator of topic in that most text units classed as forward-looking in terms or the time dimension will also be classed as forward-looking in terms of topic.

${ }^{16}$ To preserve the context of text units upon retrieval, sentences to be split into $\mathrm{x}$ text units were repeated $x$ times in the document, with the relevant section highlighted in uppercase.

${ }^{17}$ To speed up the process of online coding, add-indexing command files were used.
} 
Construct validity is achieved through the use of a classification scheme that is rigorously grounded in empirical research, i.e., the Jenkins framework. This framework has become widely accepted and has been used extensively by researchers in disclosure index studies.

\section{The Disclosure Profile}

Although the coding to the four dimensions in our classification scheme is applied independently, rather than interactively or conditionally, the frequency of code combinations across dimensions can be extracted. This has the potential to provide a rich understanding of disclosures. The quantitative analysis of data made use of the 'index search' features of NUD*IST, in particular the 'union' and 'intersect' operators. To perform an analysis on individual companies, each document was coded to a free node, so that the search could be restricted to a specific document (company). The following six forms of analysis are undertaken:

1. one-way main topic analysis, based on level 1 categories;

2. nine separate one-way sub-topic analyses, based on level 2 categories;

3. one-way analysis of each of the three type dimensions (i.e., TIME; FIN; QUAN), including level 2 categories for the QUAN dimension;

4. two-way cross-type analysis, based on level 1 categories (i.e., TIME $\times$ FIN; FIN $\times$ QUAN; TIME $\times$ QUAN);

5. three-way cross-type analysis, based on level 1 categories (i.e., TIME $\times$ FIN $\times$ QUAN); and

6. full four-way analysis.

For each unit of analysis (company or sector) key data was extracted from NUD*IST using command files and transferred to Excel spreadsheets for subsequent manipulation and analysis. Essentially, for each unit of analysis, a data matrix was produced that shows the number of text units falling into each of the possible category combinations. The results of these analyses can be portrayed either in tables or graphs. Together, they provide a comprehensive Disclosure Profile ${ }^{\mathrm{TM}}$ for individual companies or for groups of companies (e.g., an industry sector). ${ }^{18}$ Benchmarks can be

\footnotetext{
${ }^{18}$ It would also be possible to investigate other aspects of the data set, for example, patterns within the document could be analysed, or location within sections could be investigated. The latter issue is explored in Beattie, McInnes and Fearnley (2004).
} 
added to facilitate meaningful comparisons (either industry averages, acknowledged disclosure leaders within the industry, or year-on-year figures).

This methodology has been applied to companies in the UK food sector, generating rich descriptive profiles (Beattie, McInnes and Fearnley, 2002b). It has also influenced the research design and direction of several recent empirical studies, most of which are currently at the working paper stage of development (e.g., Hussainey, Schleicher and Walker, 2003; Hussainey, 2004; Atmadja and Tarca, 2004; Beretta and Bozzolan; and Nielsen, 2004a,b). Of particular note is the study by Hussainey, which attempts to partially automate the identification of forward-looking disclosures. Unfortunately, compared to manual coding, the computer is able to correctly identify only $55 \%$ of such disclosures $(2004$, p. 152$)$.

\section{ILLUSTRATION OF DISCLOSURE PROFILE}

To illustrate the type of analysis that can be undertaken, this paper focuses on a single company's 1999 voluntary annual report disclosures (Cadbury Schweppes plc, a member of industry sector 435, Food Processors). To provide a benchmark for comparison, we also report the results for a representative sample of 11 companies in that sector (which includes Cadbury Schweppes).

The document for Cadbury Schweppes plc contains 1,692 text units, excluding subheaders and sub-sub-headers. The main data table extracted from NUD*IST consists of a matrix of 108 cells, made up of 9 main topic categories by 12 main type combinations.

\section{One-way main topic analysis}

The distribution of disclosures across the nine main topic categories is shown in Table 1. It is immediately clear that the distribution is extremely unbalanced. For the sector as a whole, three categories together account for $70 \%$ of all disclosures and these categories are: business description, financial information and management and shareholders information. Cadbury Schweppes' profile is broadly similar to that for the sector, although they disclose relatively more management analysis and forward- 
looking information than the sector as a whole. These are main topic categories considered to be of particular value.

[Table 1 about here]

\section{Nine separate one-way sub-topic analyses}

The distribution of disclosures across the 79 sub-topic categories is shown in Table 2. This table also shows the full list of sub-topic categories. Within each main topic, the distribution is extremely unbalanced, with one or two items in each main topic accounting for the majority of disclosures in that main topic. For example, profit and sales disclosures dominate financial information, while reasons for change in market acceptance and in profitability dominate management analysis.

[Table 2 about here]

The profile for the company is broadly similar to that for the sector, although there are one or two marked differences. Compared to the sector as a whole, Cadbury Schweppes say more about the general development of the business, sales, cashflow, identity and effect of key macroeconomic trends, revenues, employee involvement and fulfilment and nature and cause of risks. They say less about processes and productivity.

One-way, two-way and three-way type analyses

Table 3 shows the results for each type dimension. Of particular note is that only $13 \%$ of all disclosures are forward-looking (both for Cadbury Schweppes and the sector). Cadbury Schweppes provides markedly more quantitative disclosures that the sector as a whole, which may be attributable to their US listing.

[Table 3 about here]

\section{Four-way analysis of main topic/type interactions}

The topic/type interactions at the main topic level are shown in Table 4. The bottom rows give the split of all disclosures into the 12 possible type combination categories. It can be seen that $36 \%$ of all disclosures are historical, non-financial and nonquantitative in nature, followed by $21 \%$ that are historical, financial and quantitative. 
Quantified forward-looking disclosures are a rarity. Looking at the individual main topics, Cadbury Schweppes provides rather more broad objectives and strategy disclosures that are forward-looking, non-financial and non-quantitative than the sector. It also provides more historical, financial and quantitative disclosures for many main topics.

[Table 4 about here]

\section{QUALITY: MEANING, DIMENSIONS AND PROXIES}

\section{The meaning of quality}

The 'quality' of narrative accounting disclosures can be defined in a variety of ways, suggesting that it is a complex, multi-faceted concept. For example, analytical studies define disclosure quality in terms of the precision of a Bayesian investor's beliefs about security value after receiving the disclosure (e.g., Diamond and Verrecchia, 1991). Other studies define disclosure quality as the degree of self-interested bias in the disclosure (e.g., King, 1996), while yet others define quality as the ease with which investors can read and interpret the information (e.g., Hopkins, 1996).

'Quality' is a key concept in many fields of research (e.g., quality of life, quality of food, and quality of service provision). The complex, context-sensitive and subjective nature of the concept is apparent in all cases. Some writers argue that indices that collapse measures of different dimensions (or attributes) into a single abstract value have limited appeal (e.g., Pullen, 1993; Cooley, 1998). Others perceive utility in such summary measures (e.g., Dedhiya and Kong, 1995). The present paper argues for the value of both composite summary measures and measures of individual quality dimensions. Composite summary measures are useful in relating disclosure quality to other variables of interest. However, to obtain a rich understanding of disclosure quality, it is necessary to focus on the individual dimensions, their inter-relationships and the way in which they combine. 


\section{Disclosure quality dimensions and possible proxies}

The present paper tentatively identifies several dimensions of disclosure quality that can be expected to command reasonably widespread support. ${ }^{19}$ It is argued here that a primary dimension of disclosure quality is likely to be the actual amount of disclosure, relative to the amount expected given the company's size and complexity (two variables shown to have a strong association with disclosure quantity). Companies that say relatively more can be expected to provide disclosure of higher quality, all other things being equal. The standardised residuals (variable label StdRes) from a regression of the number of text units on size and complexity are proposed as a measure of the relative amount of disclosure. ${ }^{20}$ Clearly, the larger the standardised residual, the greater the relative amount of disclosure.

However, relative amount is only one quality dimension. Another dimension is the spread of disclosures across topics, with a degree of balance (though not necessarily equal coverage) seeming desirable. It is suggested that a range of measures of spread be used. The Herfindahl index, a concentration measure, is calculated as $H=\sum_{i=1}^{n} p_{i}{ }^{2}$, where $\mathrm{p}_{\mathrm{i}}=$ proportion of disclosures in topic $\mathrm{i}$. The $\mathrm{H}$ statistic has a maximum value of 1 when all text units fall into one topic category and a minimum value of $1 / \mathrm{n}$ when the text units are spread evenly. The higher the $\mathrm{H}$ index, the poorer the spread. This index can be calculated at both the main topic level and the sub-topic level (labelled MainH and SubH, respectively). Another way of assessing spread is to count the number of non-empty sub-topics, i.e. for how many sub-topics does a company make at least one disclosure? In this case, a higher number of non-empty sub-topics indicates a better spread. ${ }^{21}$

Table 5 presents the Pearson correlations between these four measures capturing the amount and spread dimensions of disclosure. It is to be expected that the quality dimensions will be associated with each other and the correlation coefficients are

\footnotetext{
${ }^{19}$ It must, however, be emphasised that no definitive set of quality attributes and weightings of those attributes exists, since quality is subjective and context-dependent.

${ }^{20}$ Size was measured using market capitalisation $(\log 10)$ and complexity was measured as the number of business segments. For the sample of $11 \mathrm{UK}$ food processing companies, this regression model was significant $(F=12.2)$ with an $\mathrm{R}^{2}=0.69$, however only the size variable was significant at the $5 \%$ level.

${ }^{21}$ It is not suggested that this measure be applied at the main topic level as companies nearly always say something about each main topic.
} 
generally in the expected direction. (The exception is StdRes and MainH, where a negative coefficient is expected - greater relative disclosure being associated with less concentration (i.e., greater spread)). However only one of the coefficients is significant at the 5\% level (SubH and NonEmp). This may be because of the small sample size and/or the fact that the proxies capture different (though related) aspects of the underlying quality dimension. The apparent link between the proxies, suggests, however, that the measures have construct validity.

[Table 5 about here]

To provide an overall measure of quality, these four measures can be combined to create a composite measure $\mathrm{Q}_{\mathrm{c}}$. Given the variation in scale between the $\mathrm{H}$ index and the number of non-empty sub-topics, the three spread variables are first standardised. Further, to maintain comparability of interpretation, the $\mathrm{H}$ indices have also been reversed (i.e., $1-\mathrm{H}$ ), so that higher values indicate better spread. The three new spread variables are termed RStdMainH, RStdSubH and StdNonEmp. Thus, for all four quality proxies proposed, standardised values are used and higher values are considered desirable. A composite measure can now be defined as follows:

$$
\mathrm{Q}_{\mathrm{c}}=\underset{\mathrm{i}=1}{\sum \mathrm{q}_{\mathrm{i}} / 4}
$$

where $\mathrm{q}_{\mathrm{i}}=$ proxy for quality dimension.

The values for the four quality proxies are shown in Table 6 together with the composite quality measure $\mathrm{Q}_{\mathrm{c}}$ and the overall quality ranking of Cadbury Schweppes. Focussing on $\mathrm{Q}_{\mathrm{c}}$ (penultimate and final columns), Cadbury Schweppes emerges as having the best set of disclosures.

[Table 6 about here]

\section{SUMMARY AND CONCLUSIONS}

The importance of public voluntary disclosures made by listed companies is expected to increase in the future. To date, all studies that apply content-analytic methods to 
narratives have been either specific or, if more general, they have been partial. That is, studies have either focused on particular topics (such as social and environmental disclosures) or have specified a broad-based set of information items ex ante and ignored any disclosures that fall outside that list. To the best of our knowledge, no study has undertaken a general, comprehensive, sequential, unit-by-unit analysis of all disclosures.

This paper introduces to the academic literature a new, computer-assisted methodology for documenting the nature of a company's voluntary narrative disclosures based on a four-dimensional framework that captures, for each text unit, not only the topic but also three type attributes: time orientation; financial orientation and quantitative orientation. The topic analysis is based upon the comprehensive model of business reporting proposed in the Jenkins Report (AICPA, 1994). The procedures used permit the dimensions to be analysed both individually and in combination, allowing a rich description of the nature and patterns of disclosure to emerge. The emphasis given to particular topic categories can be readily calculated. Moreover, the sequential, unit-by-unit nature of the procedures used not only provides a complete, holistic view of a company's disclosures based on frequency counts, it could also be used to analyse patterns within the flow of the text. A further advantage of this method is that, because all voluntary disclosures are included, it avoids the need to select items and hence the need to specify a user group.

Specifically, a Disclosure Profile is proposed that comprises six forms of analysis: a one-way main topic analysis; nine separate one-way sub-topic analyses; one-way analyses of each of the three type dimensions; two-way cross-type analyses; threeway cross-type analysis; and full four-way analysis of topic/type interactions. This analysis can be conducted at the level of the individual company, sector or even country. With the addition of suitable benchmarks of interest (e.g., prior period, sector average) this profile represents a powerful tool for evaluating company practices both cross-sectionally and over time. In addition to this practical application, the methodology offers the potential for developing a set of metrics that could be used to facilitate academic research into voluntary disclosure (an area where there is seen to be great opportunities). 
A second objective of the paper was to suggest possible new measures of dimensions of disclosure quality. Recent reviews have emphasised the importance of developing improved measures of disclosure quality (Core, 2001) and the development of $Q_{c}$ and its components is an attempt to respond to this call. It was argued that the amount of disclosure relative to size and complexity and the spread of disclosure across main topics and sub-topics are two fundamental dimensions of quality. A composite index of disclosure quality $\left(\mathrm{Q}_{\mathrm{c}}\right)$ was created based on four measures. The suggested composite index is tentative and exploratory.

Inevitably, the method is very labour-intensive. However, in the absence of alternative narrative disclosure metrics such as subjective analyst rankings, the importance of voluntary disclosures makes it imperative that metrics be developed. ${ }^{22}$ Voluntary disclosures are important to companies, to their stakeholders/information intermediaries and to researchers as a means of advancing our understanding of major issues (such as the link between enhanced disclosure and the functioning of the capital market). Attempts to partially automate the coding have had limited success (Hussainey, 2004). A certain amount of labour-intensive manual coding is essential as the output from manual coding establishes a valid benchmark against which other procedures and proxy measures can be assessed.

All research methods suffer from limitations and, in the case of the methods used in the present study, two key limitations can be identified. First, there is inherent subjectivity involved in the coding scheme used. However the coding instrument was developed rigorously and produces high reliability measures. Second, due to the highly labour-intensive nature of the data collection and analysis procedures, generally only a small number of companies can be investigated. These two limitations must be weighed against the potential to gain new insights into disclosure practices and patterns through micro-level analysis.

Researchers investigating the determinants and consequences of disclosure quality could be wasting their efforts if the primary variable of interest is not being measured with a sufficient degree of accuracy. In this regard, the use of measures that 
simplistically equate absolute quantity with quality is a concern. A major contribution of this paper is to suggest a new direction in the measurement of disclosure quality. It is emphasised, however, that the present study is exploratory in nature and hence the suggestions made are tentative and incomplete. Further research that builds on and extends the ideas presented in this paper is essential. The incorporation of type-based quality dimensions, and (perhaps more importantly) topic/type quality dimensions, will further refine the composite quality index. The contribution to quality made by the type attributes is rather unclear, and may depend on the topic being discussed. It would also be interesting to elicit from key user groups (or a group of acknowledged experts) their views regarding the identity and nature of quality dimensions and the appropriate weightings to be assigned to each in constructing a composite quality index. Of course, these weightings may vary depending upon the decision-context, reporting company characteristics and user characteristics.

\footnotetext{
${ }^{22}$ Of course, even subjective analysts' rankings are not costless to society as a whole. Although they are costlessly available to the researcher, the analyst panels involved expend a considerable amount of time in generating them.
} 


\section{REFERENCES}

AICPA (1994). Improving Business Reporting - A Customer Focus: Meeting the Information Needs of Investors and Creditors, Comprehensive Report of the Special Committee on Financial Reporting (The Jenkins Report), New York, NY: American Institute of Certified Public Accountants.

ASB (1993). Operating and Financial Review, London: Accounting Standards Board.

ASB (2003). Operating and Financial Review, London: Accounting Standards Board.

Atmadja, N. and Tarca, A. (2004). Accounting Standard Setting for Management Reports: An Investigation of the Use of a Mandatory Standard in a Principlesbased Environment. Working Paper, University of Western Australia.

Barron, O.E., Kile, C.O. and O'Keefe, T.B. (1999). MD\&A Quality as Measured by the SEC and Analysts' Earnings Forecasts. Contemporary Accounting Research, 16(1): 75-109.

Beattie, V. A. (2000). The Future of Corporate Reporting: A Review Article. Irish Accounting Review, 7(1): 1-36.

Beattie, V., McInnes, B. and Fearnley, S. (2001). The Analysis of Narratives in Annual Reports: A Multidimensional Framework. Working Paper, University of Stirling.

Beattie, V., McInnes, B. and Fearnley, S. (2002a). 'Narrative Reporting by Listed UK Companies: A Comparative Within-sector Topic Analysis. Working Paper, University of Stirling.

Beattie, V., McInnes, B. and Fearnley, S. (2002b). Through the Eyes of Management: A Study of Narrative Disclosures, An interim report, Centre for Business Performance, London: Institute of Chartered Accountants in England and Wales.

Beattie, V., McInnes, B. and Fearnley, S. (2004). Through the Eyes of Management: Narrative Reporting Across Three Sectors, final report, Centre for Business Performance, London: Institute of Chartered Accountants in England and Wales, forthcoming.

Beretta, S. and Bozzolan, S. (2004). Assessing the Quality of Narrative Disclosure. Working Paper, University of Padova.

Botosan, C.A. (1997). Disclosure Level and the Cost of Equity Capital. The Accounting Review, July, 72(3): 323-349.

Botosan, C.A. and Plumlee, M.A. (2002). A Re-examination of Disclosure Level and the Expected Cost of Equity Capital, Journal of Accounting Research, 40(1): 2140 . 
Boyatzis, R.E. (1998). Transforming Qualitative Information: Thematic Analysis and Code Development, Thousand Oaks, CA: Sage Publications.

Bushee, B.J. and Noe, C.F. (2000). Corporate Disclosure Practices, Institutional Investors and Stock Return Volatility. Journal of Accounting Research, 38(Supplement): 171-202.

Byard, D. and Shaw, K.W. (2003). Corporate Disclosure Quality and Properties of Analysts' Information Environment. Journal of Accounting, Auditing and Finance, 18(3): 355-378.

Camfferman, K. (1997). Voluntary Annual Report Disclosures by Listed Dutch Companies, 1945-1983, New York and London: Garland Publishing.

CICA (1991). Information to be Included in the Annual Report to Shareholders, Toronto, Ontario: Canadian Institute of Chartered Accountants.

CICA (2002). Management's Discussion and Analysis: Guidance on Preparation and Disclosure, Toronto, Ontario: Canadian Institute of Chartered Accountants.

Clarkson, P.M., Kao, J.L. and Richardson, G.D. (1999). Evidence That Management Discussion and Analysis (MD\&A) is a Part of a Firm's Overall Disclosure Package. Contemporary Accounting Research, 16(1): 111-134.

Cooley, M.E. (1998). Quality of Life in Persons with Non-small Cell Lung Cancer: A Concept Analysis. Cancer Nursing, 21(3): 151-161.

Core, J.E. (2001). A Review of the Empirical Disclosure Literature. Journal of Accounting and Economics, 31(3): 441-456.

Courtis, J.K. (1998). Annual Report Readability Variability: Tests of the Obfuscation Hypothesis. Accounting, Auditing \& Accountability Journal, 11(4): 459-471.

De Beaugrande, R. and Dressler, W. (1981). Introduction to Text Linguistics, London and New York, NY: Longman.

Dedhiya, S. and Kong, S.X. (1995). Quality of Life - An Overview of the Concept and Measures. Pharmacy World \& Science, 17(5): 141-148.

Diamond, D.W. and Verrecchia, R.E. (1991). Disclosure, Liquidity, and the Cost of Capital. Journal of Finance, 66(September): 1325-1355.

DTI (2002). Modernising Company Law, White Paper, Cmnd 5553, London: Department of Trade and Industry.

DTI (2004). Draft Regulations on the Operating and Financial Review and Directors' Report: A Consultative Document, London: Department of Trade and Industry.

Elliott, R. K. (1992). The Third Wave Breaks on the Shores of Accounting. Accounting Horizons, 6(2): 61-85. 
FASB (2001a). Business and Financial Reporting, Challenges from the New Economy Special Report, Financial Accounting Standards Board.

FASB (2001b). Improving Business Reporting: Insights into Enhancing Voluntary Disclosures, Steering Committee Report, Business Reporting Research Project, Financial Accounting Standards Board.

G100 (2003). The Group of 100 Welcomes MD\&A Inclusion in CLERP 9 Proposals. [available at http://www.group100.com.au/media/mr_20031009.htm]

Gahen, C. and Hannibal, M. (1998). Doing Qualitative Research Using QSR $N U D^{*} I S T$, London: Sage Publications.

Gelb, D.S. and Zarowin, P. (2002). Corporate Disclosure Policy and the Informativeness of Stock Prices. Review of Accounting Studies, 7(1): 33-52.

Guthrie, J. and Mathews, M.R. (1985). Corporate Social Accounting in Australasia, in Preston, L.E. (ed.), Research in Corporate Social Performance and Policy, 7: 251277.

Healy, P.M., Hutton, A.P. and Palepu, K.G. (1999). Stock Performance and Intermediation Changes Surrounding Sustained Increases in Disclosure. Contemporary Accounting Research, 16(3): 485-524.

Healy, P.M. and Palepu, K.G. (2001). Information Asymmetry, Corporate Disclosure, and the Capital Markets: A Review of the Empirical Disclosure Literature. Journal of Accounting and Economics, 31(3): 405-440.

Holsti, O.R. (1969). Content Analysis for the Social Sciences and Humanities, Reading, MA: Addison-Wesley.

Hopkins, P. (1996). The Effect of Financial Statement Classification of Hybrid Financial Instruments on Financial Analysts' Stock Price Judgments. Journal of Accounting Research, Supplement: 33-50.

Hussainey, K. (2004). A Study of the Ability of Partially Automated Disclosure Scores to Explain the Information Content of Annual Report Narratives for Future Earnings. PhD Thesis, University of Manchester.

Hussainey, K., Schleicher, T. and Walker, M. (2003). Undertaking Large-scale Disclosure Studies when AIMR-FAF Ratings are not Available: the Case of Prices Leading Earnings. Accounting and Business Research, 33(4): 275-294.

ICAEW (2003). New Reporting Models for Business, London: Institute of Chartered Accountants in England and Wales.

ICAS (1999). Business Reporting: The Inevitable Change?, Beattie, V. (ed.), Edinburgh: Institute of Chartered Accountants of Scotland. 
Imhoff, E.A. (1992). The Relation between Perceived Accounting Quality and Economic Characteristics of the Firm. Journal of Accounting and Public Policy, 11(Summer): 97-118.

Jones, M.J. and Shoemaker, P.A. (1994). Accounting Narratives: A Review of Empirical Studies of Content and Readability. Journal of Accounting Literature, 13: 142-184.

King, R. (1996). Reputation Formation for Reliable Reporting: An Experimental Investigation. The Accounting Review, 71(3): 375-396.

Krippendorff, K. (1980), Content Analysis: An Introduction to its Methodology, Beverly Hills, CA: Sage Publications.

Lang, M. and Lundholm, R. (1993). Cross-Sectional Determinants of Analyst Ratings of Corporate Disclosures. Journal of Accounting Research, 31(2): 246-271.

Lang, M.H. and Lundholm, R.J. (1996). Corporate Disclosure Policy and Analyst Behaviour. The Accounting Review, 71(4): 467-492.

Lang, M.H. and Lundholm, R.J. (2000). Voluntary Disclosure and Equity offerings: Reducing Information Asymmetry or Hyping the Stock? Contemporary Accounting Research, 17(4): 623-669.

Lev, B. (2001). Intangibles: Management, Measurement and Reporting, Brookings Institution Press.

Lev, B. and Zarowin, P. (1999). The Boundaries of Financial Reporting and How to Extend Them. Journal of Accounting Research, 37(2): 353-385.

Lundholm, R.J. and Myers, L.A. (2002). Bringing the Future Forward: The Effect of Disclosure on the Return-earnings Relation. Journal of Accounting Research, 40(3): 809-839.

Marston, C.L. and Shrives, P.J. (1991). The Use of Disclosure Indices in Accounting Research: A Review Article. British Accounting Review, 23(3): 195-210.

Milne, M.J. and Adler, R.W. (1999). Exploring the Reliability of Social and Environmental Disclosures Content Analysis', Accounting, Auditing and Accountability Journal, 12(2): 237-256.

Nielsen, C. (2004a). Through the Eyes of Analysts: A Content Analysis of Annual Report Narratives. Working Paper, Copenhagen Business School.

Nielsen, C. (2004a). New Reporting Models - Plethora or Pertinent. Working Paper, Copenhagen Business School.

Pullen, W.T. (1993). Definition and Measurement of Quality of Service for Local Public Transport Management. Transport Reviews, 13(3): 247-264.

QSR (1997). QSR NUD*IST 4 User Guide, Second edition, Scolari, Sage Publications Software. 
Robb, S.W.G., Single, L.E. and Zarzeski, M.T. (2001). Nonfinancial Disclosures Across Anglo-American Countries. Journal of International Accounting, 10(1): 7183.

Roseberry, R.L. (1995). A Texture Index: Measuring Texture in Discourse. International Journal of Applied Linguistics, 5(2): 205-223.

Rutherford, B.A. (2002). Half the Story: Progress and Prospects for the Operating and Financial Review, ACCA Research Report No.80, London: Certified Accountants Educational Trust.

Schleicher, T. (1998). Developments in Corporate Financial Disclosure over the Period 1975-1996: Evidence from UK Annual Reports. Occasional Research Paper No.21, London: Association of Chartered Certified Accountants.

SEC (2003). Final Rule: Disclosure in Management's Discussion and Analysis about Off-balance Sheet Arrangements and Aggregate Contractual Obligations, Washington DC: Securities and Exchange Commission.

Sengupta, P. (1998). Corporate Disclosure Quality and the Cost of Debt. The Accounting Review, 73(4): 459-474.

Smith, M. and Taffler, R.J. (2000). The Chairman's Statement: A Content Analysis of Discretionary Narrative Disclosures. Accounting, Auditing and Accountability Journal, 13(5): 624-646.

Sydserff, R. and Weetman, P. (1999). A Texture Index for Evaluating Accounting Narratives: An Alternative to Readability Formulas. Accounting, Auditing and Accountability Journal, 12(4): 459-488.

SRI International (1987). Investor Information Needs and the Annual Report, Morristown, NJ: Financial Executives Research Foundation.

van Reil, C.B.M. (1997). Research in Corporate Communication: An Overview of an Emerging Field. Management Communication Quarterly, 11(2): 288-309.

Vanstraelen, A., Zarzeski, M.T. and Robb, S.W.G. (2003). Corporate Nonfinancial Disclosure Practices and Financial Analyst Forecast Ability Across Three European Countries. Journal of International Financial Management and Accounting, 14(3): 249-278.

Wallman, S.M.H. (1995). The Future of Accounting and Disclosure in an Evolving World: The Need for Dramatic Change. Accounting Horizons, 9(3): 81-91.

Wallman, S.M.H. (1996). The Future of Accounting and Financial Reporting Part II: The Colorized Approach. Accounting Horizons, 10(2): 138-148.

Wallman, S.M.H. (1997). The Future of Accounting and Financial Reporting, Part IV: "Access" Accounting. Accounting Horizons, 11(2): 103-116. 
Weber, R.P. (1985). Basic Content Analysis, Quantitative Applications in the Social Sciences, No. 49, Beverly Hills, CA: Sage Publications.

Welker, M. (1995). Disclosure Policy, Information Asymmetry, and Liquidity in Equity Markets. Contemporary Accounting Research, 11(2): 801-827. 
Figure 1: Approaches to the Analysis of Narratives in Annual Reports

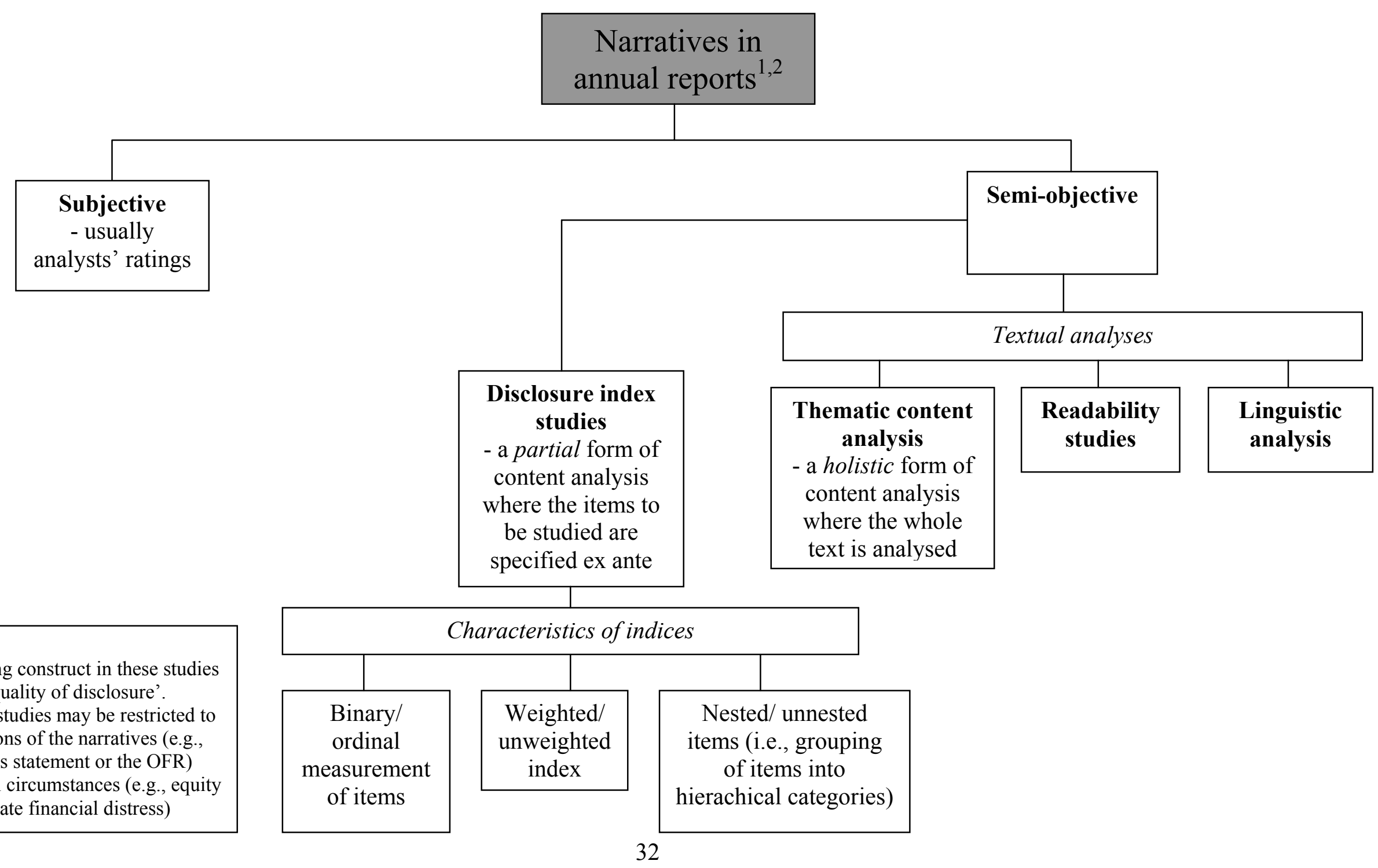


Figure 2: Architecture of Coding Scheme for Voluntary Disclosures

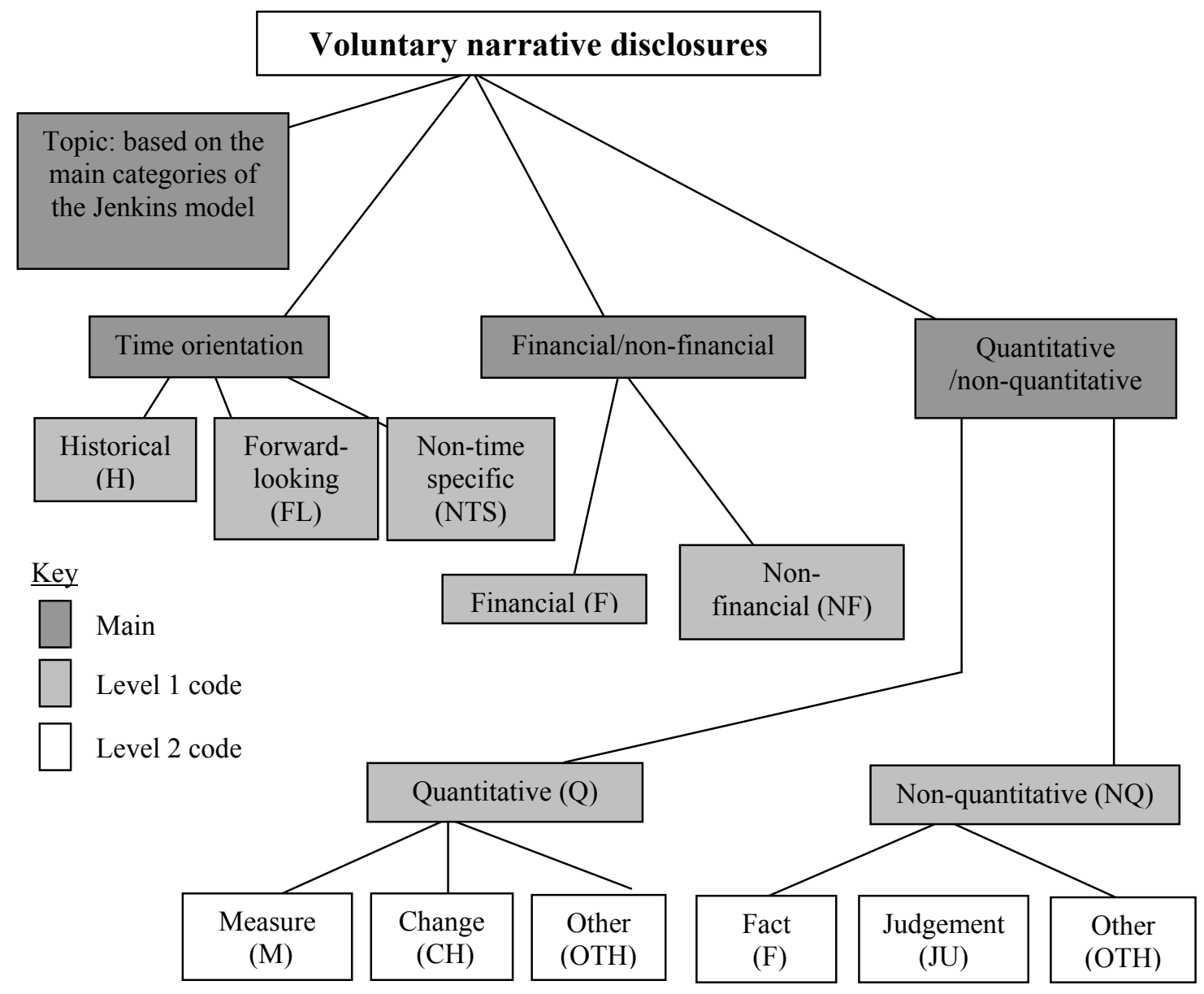




\section{Figure 3: Illustration of Sentence Splits to Create Text Units}

Sentence: Profits were $£ X$ in for the year, with profits next year expected to increase due to anticipated market growth.

Sentence

Coding stage 1:

Time orientation

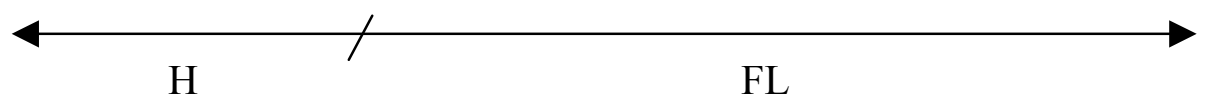

Coding stage 2:

Financial/non-financial

orientation

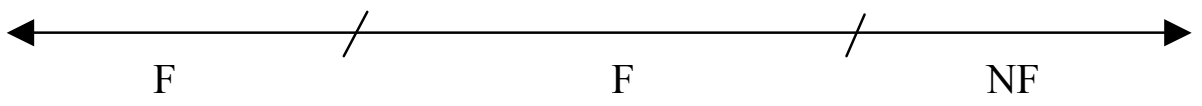

Coding stage 3:

Quantitative/non-quantitative orientation

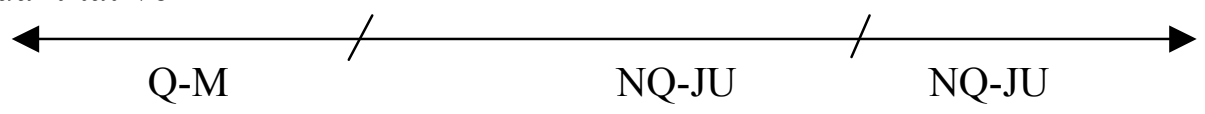

Coding stage 4:

topic and sub-topic

FIN-PROF

MA-PROF 
Figure 4: Extract from Coding Instrument

\begin{tabular}{|c|c|c|c|c|}
\hline Category & Code & Definition & Flags, Qualifications \& Exclusions & Examples \\
\hline $\begin{array}{l}\text { Financial/non- } \\
\text { financial } \\
\text { orientation }\end{array}$ & $\mathrm{F}$ & Financial & $\begin{array}{l}\text { Usually use of financial topic keyword } \\
\text { Can be financial values with no financial variable } \\
\text { Need not be quantitative } \\
\text { The description of treasury policies (e.g. financial } \\
\text { instruments and derivatives) that inevitably includes a lot } \\
\text { of financial topic keywords } \\
\text { Description of financial controls } \\
\text { Reference to some financial aspect, e.g. investment, value } \\
\text { to shareholders, contribution, spend, pension holiday, costs } \\
\text { Discussion of accounting standards and policies } \\
\text { Vague terms such as performance, result treated as } \\
\text { financial only if clear from context that refers to a financial } \\
\text { measure. }\end{array}$ & $\begin{array}{l}\text { Dividends increased 5.0\%. } \\
\text { The acquisition of Star Dairies in London for } £ 3.5 \text { million in February } 1999 \\
\text { Our strong cash flow } \\
\text { This was ahead of the margin achieved in the previous year } \\
\text { Financial instruments (including swaps, caps, collars and forward rate } \\
\text { agreements) are used to manage and limit the group’s exposure to adverse } \\
\text { movements in interest rates } \\
\text { Investment in new equipment at our Ashby dairy } \\
\text { The combination of these initiatives gives us confidence in our ability to } \\
\text { deliver growing value to our shareholders in the future } \\
\text {...and an increase in the underlying contribution from our major retail } \\
\text { business } \\
\text { The group's purchased brands are not amortised since they are regarded as } \\
\text { having indefinite useful economic lives }\end{array}$ \\
\hline
\end{tabular}


Table 1: Distribution of Cadbury Schweppes Text Units across Main Topics

\begin{tabular}{||l|l||c|c||c|c||}
\hline \multirow{2}{*}{ Code } & \multirow{2}{*}{ Main topic } & \multicolumn{2}{|c||}{ Cadbury Schweppes } & \multicolumn{2}{|c||}{ Food sector } \\
\cline { 2 - 6 } & & Text units & $\mathbf{\%}$ & Text units & $\%$ \\
\hline BD & Business Description & 582 & 34.3 & 2,423 & 36.9 \\
\hline FIN & Financial Information & 332 & 19.6 & 1,287 & 19.6 \\
\hline MA & Management Analysis & 228 & 13.5 & 486 & 7.4 \\
\hline MS & Management \& Shareholder Information & 164 & 9.7 & 860 & 13.1 \\
\hline OP & Operating Data & 137 & 8.1 & 525 & 8.0 \\
\hline FL & Forward Looking Information & 129 & 7.6 & 433 & 6.6 \\
\hline NOT & Not Jenkins & 52 & 3.1 & 347 & 5.3 \\
\hline BOS & Broad Objectives and Strategy & 50 & 3.0 & 163 & 2.5 \\
\hline IS & Industry Structure & 18 & 1.1 & 40 & 0.6 \\
\hline & & $\mathbf{1 , 6 9 2}$ & $\mathbf{1 0 0 . 0}$ & $\mathbf{6 , 5 6 4}$ & $\mathbf{1 0 0 . 0}$ \\
\hline
\end{tabular}


Table 2: Distribution of Cadbury Schweppes Text Units across Sub-topics

\begin{tabular}{|c|c|c|c|c|}
\hline \multirow[b]{2}{*}{ Code } & \multirow[b]{2}{*}{ Description } & \multicolumn{2}{|c|}{ Cadbury Schweppes } & \multirow{2}{*}{$\begin{array}{c}\text { Food } \\
\text { sector } \\
\%\end{array}$} \\
\hline & & $\begin{array}{l}\text { Text } \\
\text { units }\end{array}$ & $\%$ & \\
\hline$B D$ & \multicolumn{4}{|l|}{ Business Description } \\
\hline BUS & General development of business & 200 & 34.4 & 25.4 \\
\hline PROD & Principal products/services & 139 & 23.9 & 20.4 \\
\hline MKT & Principal markets and market segments & 70 & 12.0 & 11.4 \\
\hline PRO & Processes & 26 & 4.5 & 9.1 \\
\hline MAC & $\begin{array}{l}\text { Types of macroeconomic activity that management believes are } \\
\text { closely correlated with business revenues or expenses }\end{array}$ & 26 & 4.5 & 2.1 \\
\hline PAT & Description of important patents, trademarks licenses, franchises etc. & 24 & 4.1 & 1.3 \\
\hline PROPS & Location, nature, capacity and utilization of physical properties & 20 & 3.4 & 5.8 \\
\hline RELA & Major contractual relationships & 20 & 3.4 & 2.6 \\
\hline INP & Key inputs & 18 & 3.1 & 2.8 \\
\hline REG & $\begin{array}{l}\text { Existing and proposed laws and regulations that could impact business } \\
\text { significantly }\end{array}$ & 14 & 2.4 & 1.8 \\
\hline DIST & Distribution and delivery methods & 13 & 2.2 & 2.0 \\
\hline IND & Industry & 7 & 1.2 & 14.9 \\
\hline SEAS & Seasonality and cyclicality & 5 & 0.9 & 0.2 \\
\hline \multicolumn{2}{|r|}{ Total } & 582 & 100.0 & 100.0 \\
\hline$F I N$ & \multicolumn{4}{|l|}{ Financial Information } \\
\hline PROF & Profit \& profitability measures, including EPS & 112 & 33.7 & 36.3 \\
\hline SAL & Sales & 92 & 27.7 & 20.1 \\
\hline $\mathrm{CF}$ & Cashflow & 32 & 9.7 & 4.9 \\
\hline $\mathrm{OTH}$ & Other & 28 & 8.4 & 14.9 \\
\hline DEBT & Debt & 26 & 7.9 & 7.5 \\
\hline GEAR & Gearing & 9 & 2.7 & 2.0 \\
\hline INT & Interest & 7 & 2.1 & 1.9 \\
\hline TAX & Tax & 6 & 1.8 & 2.6 \\
\hline CAPEX & Capital expenditure & 5 & 1.5 & 1.6 \\
\hline WC & Working capital & 5 & 1.5 & 1.1 \\
\hline INTCOV & Interest cover & 4 & 1.2 & 1.2 \\
\hline DIV & Dividends & 3 & 0.9 & 5.7 \\
\hline PENS & Pensions & 3 & 0.9 & 0.2 \\
\hline & Total & 332 & 100.0 & 100.0 \\
\hline
\end{tabular}

Cont./- 
Table 2 (cont.): Distribution of Cadbury Schweppes Text Units across Sub-topics

\begin{tabular}{|c|c|c|c|c|}
\hline \multirow[b]{2}{*}{ Code } & \multirow[b]{2}{*}{ Description } & \multicolumn{2}{|c|}{ Cadbury Schweppes } & \multirow{2}{*}{$\begin{array}{l}\text { Food } \\
\text { sector } \\
\% \\
\end{array}$} \\
\hline & & $\begin{array}{l}\text { Text } \\
\text { units }\end{array}$ & $\%$ & \\
\hline$M A$ & \multicolumn{4}{|l|}{ Management Analysis } \\
\hline MKT & Reasons for change in market acceptance & 79 & 34.6 & 32.9 \\
\hline PROF & Reasons for change in profitability & 72 & 31.6 & 37.2 \\
\hline MAC & Identity and past effect of key macroeconomic trends & 50 & 21.9 & 13.7 \\
\hline OTH & Reasons for change - other & 15 & 6.6 & 8.0 \\
\hline UNU & Identity, effect of unusual or nonrecurring transactions and events & 5 & 2.2 & 1.6 \\
\hline RAT & Reasons for change in ratios & 3 & 1.3 & 0.6 \\
\hline LIQ & Reasons for change in liquidity and financial flexibility & 2 & 0.9 & 1.6 \\
\hline REG & Identity and past effect of key regulatory trends & 2 & 0.9 & 0.6 \\
\hline FPOS & Reasons for change in financial position & 0 & 0.0 & 0.8 \\
\hline INN & Reasons for change in innovation & 0 & 0.0 & 0.8 \\
\hline SOC & Identity and past effect of key social trends & 0 & 0.0 & 0.6 \\
\hline TECH & Identity and past effect of key technological trends & 0 & 0.0 & 0.6 \\
\hline POL & Identity and past effect of key political trends & 0 & 0.0 & 0.6 \\
\hline DEM & Identity and past effect of key demographic trends & 0 & 0.0 & 0.4 \\
\hline \multicolumn{2}{|r|}{ Total } & 228 & 100.0 & 100.0 \\
\hline$M S$ & \multicolumn{4}{|l|}{ Management \& Shareholder Information } \\
\hline $\begin{array}{l}\text { SHAREH } \\
\text { OLDER }\end{array}$ & Identity and background of directors and executive management & 146 & 89.1 & 96.9 \\
\hline $\begin{array}{l}\text { SHAREH } \\
\text { OLDER }\end{array}$ & $\begin{array}{l}\text { Identity and number of shares owned by major owners; number of } \\
\text { shares owned by directors, management and employees, each as a } \\
\text { group }\end{array}$ & 10 & 6.1 & 1.7 \\
\hline RELA & Transactions and relationships among related parties & 4 & 2.4 & 0.9 \\
\hline COMP & $\begin{array}{l}\text { Types and amount of director and executive management } \\
\text { compensation and methods of computation }\end{array}$ & 4 & 2.4 & 0.5 \\
\hline \multirow[t]{2}{*}{ DIS } & Nature of disagreements with former business advisors & 0 & 0.0 & 0.0 \\
\hline & Tota1 & 164 & 100.0 & 100.0 \\
\hline$O P$ & \multicolumn{4}{|l|}{ Operating Data } \\
\hline REV & Revenues e.g. level and changes in units and prices, market share & 83 & 60.7 & 45.0 \\
\hline COST & $\begin{array}{l}\text { Costs, e.g. number of employees, average compensation per } \\
\text { employee }\end{array}$ & 31 & 22.7 & 25.1 \\
\hline EMP & $\begin{array}{l}\text { Employee involvement and fulfilment, e.g. level and changes in } \\
\text { employee satisfaction }\end{array}$ & 11 & 8.0 & 4.2 \\
\hline PRODY & Productivity, e.g. input/output ratio & 5 & 3.6 & 13.5 \\
\hline RES & $\begin{array}{l}\text { Amount and quality of key resources, including human resources, e.g. } \\
\text { average age }\end{array}$ & 4 & 2.9 & 4.0 \\
\hline MAT & Volume and prices of materials used & 1 & 0.7 & 3.8 \\
\hline QUAL & Quality e.g. customer satisfaction, \% defects, backlog & 1 & 0.7 & 2.5 \\
\hline INN & Innovation, e.g. \% current production designed in period & 1 & 0.7 & 1.1 \\
\hline TIME & $\begin{array}{l}\text { Time required to perform key activities, e.g. production, delivery, } \\
\text { new product development }\end{array}$ & 0 & 0.0 & 0.8 \\
\hline OUT & Outlets & 0 & 0.0 & 0.0 \\
\hline & Total & 137 & 100.0 & 100.0 \\
\hline
\end{tabular}


Table 2 (cont.): Distribution of Cadbury Schweppes Text Units across Sub-topics

\begin{tabular}{|c|c|c|c|c|}
\hline \multirow[b]{2}{*}{ Code } & \multirow[b]{2}{*}{ Description } & \multicolumn{2}{|c|}{ Cadbury Schweppes } & \multirow{2}{*}{$\begin{array}{l}\text { Food } \\
\text { sector } \\
\quad \% \\
\end{array}$} \\
\hline & & \begin{tabular}{|l|} 
Text \\
units \\
\end{tabular} & $\%$ & \\
\hline$F L$ & \multicolumn{4}{|l|}{ Forward Looking Information } \\
\hline PLAN & Activities and plans to meet broad objectives and business strategy & 64 & 49.6 & 54.0 \\
\hline RISK & Nature and cause of risks & 35 & 27.1 & 13.4 \\
\hline OPP & Nature and cause of opportunities & 29 & 22.5 & 22.7 \\
\hline FACINT & $\begin{array}{l}\text { Factors that management believes must be present, occurring within } \\
\text { the business }\end{array}$ & 1 & 0.8 & 1.6 \\
\hline $\mathrm{OTH}$ & Non-specific evaluation of future outcomes / performance & 0 & 0.0 & 5.5 \\
\hline FACEXT & $\begin{array}{l}\text { Factors that management believes must be present, occurring outside } \\
\text { the business }\end{array}$ & 0 & 0.0 & 1.4 \\
\hline DIFF & $\begin{array}{l}\text { Identity of major differences between actual business performance and } \\
\text { previously disclosed opportunities, risks and management plans }\end{array}$ & 0 & 0.0 & 1.4 \\
\hline \multirow[t]{2}{*}{ EFF } & $\begin{array}{l}\text { Effects of opportunities and risks on future core earnings and cash } \\
\text { flows }\end{array}$ & 0 & 0.0 & 0.0 \\
\hline & $\begin{array}{ll}2.01 & \text { Total } \\
\end{array}$ & 129 & 100.0 & 100.0 \\
\hline$N O T$ & \multicolumn{4}{|l|}{ Not Jenkins } \\
\hline EMP & Employees & 18 & 34.6 & 29.6 \\
\hline OTHLINK & Link to another part of the annual report or other source & 15 & 28.8 & 10.1 \\
\hline $\mathrm{COM}$ & Business and local community & 5 & 9.6 & 14.4 \\
\hline STD & Accounting standards and impact & 4 & 7.8 & 4.3 \\
\hline ENV & Environmental & 3 & 5.8 & 21.9 \\
\hline CUS & Customers & 3 & 5.8 & 8.4 \\
\hline OTHTH & $\begin{array}{l}\text { Thanks to / recognition of support of / expression of appreciation of } \\
\text { stakeholder group /directors }\end{array}$ & 2 & 3.8 & 6.1 \\
\hline POL & Accounting policies and impact & 2 & 3.8 & 2.6 \\
\hline CHYE & Change in financial year-end & 0 & 0.0 & 2.0 \\
\hline SUP & Suppliers & 0 & 0.0 & 0.6 \\
\hline & Total & 52 & 100.0 & 100.0 \\
\hline$B O S$ & \multicolumn{4}{|l|}{ Broad Objectives and Strategy } \\
\hline OBJ & Broad objectives, quantified where practical & 37 & 74.0 & 71.2 \\
\hline STRAT & Principal strategies to achieve objectives & 13 & 26.0 & 28.8 \\
\hline CONSIS & Discussion of consistency of strategy with key trends & 0 & 0.0 & 0.0 \\
\hline & Total & 50 & 100.0 & 100.0 \\
\hline$I S$ & \multicolumn{4}{|l|}{ Industry Structure } \\
\hline COMP & $\begin{array}{l}\text { Intensity of industry competition, dispersion of competitors and } \\
\text { identity of major competitors; measures of intensity of competition, } \\
\text { e.g. relative price changes, customer switches }\end{array}$ & 18 & 100.0 & 60.0 \\
\hline CUS & $\begin{array}{l}\text { Bargaining power of customers, extent of dispersion, including } \\
\text { concentration measure identity of dominant customers; measures of } \\
\text { relative bargaining power, e.g. recent price changes }\end{array}$ & 0 & 0.0 & 20.0 \\
\hline SUP & $\begin{array}{l}\text { Bargaining power of resource providers; identity of types of major } \\
\text { resource and related suppliers; for each type, availability of supply; } \\
\text { measures of relative bargaining power, e.g. recent price changes }\end{array}$ & 0 & 0.0 & 20.0 \\
\hline & $\begin{array}{ll} & \text { Total } \\
\end{array}$ & 18 & 100.0 & 100.0 \\
\hline
\end{tabular}


Table 3: Distribution of Cadbury Schweppes Text Units by Type

\begin{tabular}{|c|c|c|c|}
\hline \multirow[t]{2}{*}{ Type } & \multicolumn{2}{|c|}{ Cadbury Schweppes } & \multirow{2}{*}{$\frac{\text { Food sector }}{\%}$} \\
\hline & Text units & $\%$ & \\
\hline \multicolumn{4}{|l|}{ One-way analysis } \\
\hline \multicolumn{4}{|l|}{ Time dimension } \\
\hline Historical & 1,232 & 73 & 73 \\
\hline Forward-looking & 216 & 13 & 13 \\
\hline Non-time specific & 244 & 14 & 14 \\
\hline \multicolumn{4}{|l|}{ Financial / non-financial } \\
\hline Financial & 659 & 39 & 36 \\
\hline Non-financial & 1,033 & 61 & 64 \\
\hline \multicolumn{4}{|l|}{ Quantitative / non-quantitative } \\
\hline Quantitative & 472 & 28 & 19 \\
\hline Non-quantitative & 1,220 & 72 & 81 \\
\hline \multicolumn{4}{|l|}{ Two-way analysis } \\
\hline \multicolumn{4}{|l|}{ Time $\times$ Financial / non-financial } \\
\hline Historical / Financial & 550 & 32 & 30 \\
\hline Historical / non-financial & 682 & 40 & 44 \\
\hline Forward-looking / financial & 45 & 3 & 3 \\
\hline Forward-looking / non-financial & 171 & 10 & 9 \\
\hline Non-time specific / financial & 64 & 4 & 3 \\
\hline Non-time specific / non-financial & 180 & 11 & 9 \\
\hline \multicolumn{4}{|l|}{ Time $\times$ quantitative / non-quantitative } \\
\hline Historical / quantitative & 452 & 27 & 18 \\
\hline Historical / non-quantitative & 780 & 46 & 55 \\
\hline Forward-looking / quantitative & 5 & 1 & 1 \\
\hline Forward-looking / non-quantitative & 211 & 12 & 13 \\
\hline Non-time specific / quantitative & 15 & 1 & 1 \\
\hline Non-time specific / non-quantitative & 229 & 13 & 13 \\
\hline \multicolumn{4}{|c|}{ Financial / non-financial $\times$ quantitative / non-quantitative } \\
\hline Financial / quantitative & 368 & 22 & 15 \\
\hline Financial / non-quantitative & 291 & 17 & 21 \\
\hline Non-financial / quantitative & 104 & 6 & 4 \\
\hline Non-financial / non-quantitative & 929 & 55 & 60 \\
\hline \multicolumn{4}{|l|}{ Three-way analysis } \\
\hline Historical / financial / quantified & 362 & 21 & 15 \\
\hline Historical / financial / non-quantified & 188 & 11 & 15 \\
\hline Historical / non-financial / quantified & 90 & 5 & 3 \\
\hline Historical / non-financial / non-quantified & 592 & 35 & 40 \\
\hline Forward-looking / financial / quantified & 1 & 1 & 0 \\
\hline Forward-looking / financial / non-quantified & 44 & 2 & 3 \\
\hline Forward-looking / non-financial / quantified & 4 & 1 & 0 \\
\hline Forward-looking / non-financial / non-quantified & 167 & 9 & 9 \\
\hline Non-time specific / financial / quantified & 5 & 1 & 0 \\
\hline Non-time specific / financial / non-quantified & 59 & 3 & 3 \\
\hline Non-time specific / non-financial / quantified & 10 & 1 & 0 \\
\hline Non-time specific / non-financial / non-quantified & 170 & 10 & 10 \\
\hline
\end{tabular}


Table 4: Distribution of Cadbury Schweppes Text Units by Topic/Type Interaction

\begin{tabular}{|c|c|c|c|c|c|c|c|c|c|c|c|c|c|c|}
\hline \multirow[b]{2}{*}{ Code } & \multirow[b]{2}{*}{ Main topic } & & \multicolumn{12}{|c|}{ Type codes ${ }^{1}$} \\
\hline & & & $\begin{array}{l}\text { H/ } \\
\text { NF/ } \\
\text { NQ }\end{array}$ & $\begin{array}{l}\text { NTS/ } \\
\text { NF/ } \\
\text { NQ }\end{array}$ & $\begin{array}{l}\text { FL/ } \\
\text { NF/ } \\
\text { NQ }\end{array}$ & $\begin{array}{l}\mathrm{H} / \\
\mathbf{F} / \\
\text { NQ }\end{array}$ & $\begin{array}{c}\text { NTS/ } \\
\text { F/ } \\
\text { NQ }\end{array}$ & $\begin{array}{c}\text { FL/ } \\
\text { F/ } \\
\text { NQ }\end{array}$ & $\begin{array}{c}\mathbf{H} / \\
\mathbf{N F} / \\
\mathbf{Q}\end{array}$ & $\begin{array}{l}\text { NTS/ } \\
\text { NF/ } \\
\mathbf{Q}\end{array}$ & $\begin{array}{l}\mathbf{F L} / \\
\mathbf{N F} / \\
\mathbf{Q}\end{array}$ & $\begin{array}{l}\mathbf{H} / \\
\mathbf{F} / \\
\mathbf{Q}\end{array}$ & $\begin{array}{l}\text { NTS/ } \\
\text { F/ } \\
\mathbf{Q}\end{array}$ & $\begin{array}{c}\mathbf{F L} / \\
\mathbf{F} / \\
\mathbf{Q}\end{array}$ \\
\hline \multirow{2}{*}{$\mathrm{BD}$} & \multirow{2}{*}{ Business Description } & $\begin{array}{l}\text { Cadbury } \\
\text { Schweppes }\end{array}$ & 51 & 20 & 9 & 6 & 2 & 1 & 5 & 2 & 0 & 5 & 0 & 0 \\
\hline & & Food sector & 50 & 20 & 11 & 9 & 1 & 1 & 3 & 1 & 0 & 3 & 0 & 0 \\
\hline \multirow{2}{*}{ FIN } & \multirow{2}{*}{ Financial Information } & $\begin{array}{l}\text { Cadbury } \\
\text { Schweppes }\end{array}$ & 1 & 0 & 1 & 13 & 6 & 4 & 1 & 0 & 0 & 73 & 1 & 0 \\
\hline & & Food sector & 2 & 0 & 0 & 27 & 6 & 5 & 1 & 0 & 0 & 59 & 0 & 1 \\
\hline \multirow{2}{*}{ MA } & \multirow{2}{*}{ Management Analysis } & $\begin{array}{l}\text { Cadbury } \\
\text { Schweppes }\end{array}$ & 36 & 0 & 1 & 35 & 0 & 1 & 3 & 0 & 0 & 24 & 0 & 0 \\
\hline & & Food sector & 37 & 1 & 1 & 41 & 0 & 3 & 1 & 0 & 0 & 15 & 0 & 0 \\
\hline \multirow{2}{*}{ MS } & \multirow{2}{*}{$\begin{array}{l}\text { Management \& Shareholder } \\
\text { Information }\end{array}$} & $\begin{array}{l}\text { Cadbury } \\
\text { Schweppes }\end{array}$ & 80 & 4 & 7 & 8 & 0 & 0 & 0 & 0 & 0 & 5 & 0 & 0 \\
\hline & & Food sector & 93 & 2 & 3 & 1 & 0 & 0 & 0 & 0 & 0 & 1 & 0 & 0 \\
\hline \multirow{2}{*}{ OP } & \multirow{2}{*}{ Operating Data } & \begin{tabular}{|l|} 
Cadbury \\
Schweppes \\
\end{tabular} & 33 & 3 & 0 & 9 & 1 & 1 & 36 & 0 & 1 & 16 & 0 & 0 \\
\hline & & Food sector & 38 & 2 & 5 & 19 & 1 & 0 & 18 & 0 & 1 & 9 & 0 & 1 \\
\hline \multirow{2}{*}{ FL } & \multirow{2}{*}{$\begin{array}{l}\text { Forward Looking } \\
\text { Information }\end{array}$} & \begin{tabular}{|l|l} 
Cadbury \\
Schweppes \\
\end{tabular} & 9 & 11 & 47 & 1 & 19 & 12 & 0 & 0 & 0 & 0 & 2 & 0 \\
\hline & & Food sector & 8 & 8 & 48 & 8 & 10 & 13 & 0 & 0 & 1 & 2 & 1 & 2 \\
\hline \multirow{2}{*}{ NOT } & \multirow{2}{*}{ Not Jenkins } & \begin{tabular}{|l|} 
Cadbury \\
Schweppes \\
\end{tabular} & 23 & 40 & 4 & 27 & 4 & 0 & 0 & 0 & 2 & 0 & 0 & 0 \\
\hline & & Food sector & 44 & 25 & 7 & 15 & 2 & 0 & 4 & 0 & 0 & 2 & 0 & 0 \\
\hline \multirow{2}{*}{ BOS } & \multirow{2}{*}{$\begin{array}{l}\text { Broad Objectives and } \\
\text { Strategy }\end{array}$} & \begin{tabular}{|l|} 
Cadbury \\
Schweppes \\
\end{tabular} & 14 & 0 & 64 & 2 & 2 & 12 & 0 & 0 & 0 & 6 & 0 & 0 \\
\hline & & Food sector & 24 & 10 & 39 & 6 & 7 & 12 & 0 & 0 & 0 & 2 & 1 & 0 \\
\hline \multirow{2}{*}{ IS } & \multirow{2}{*}{ Industry Structure } & \begin{tabular}{|l|} 
Cadbury \\
Schweppes \\
\end{tabular} & 39 & 39 & 0 & 0 & 0 & 0 & 11 & 0 & 0 & 11 & 0 & 0 \\
\hline & & Food sector & 58 & 23 & 5 & 3 & 0 & 0 & 5 & 0 & 0 & 8 & 0 & 0 \\
\hline & \multirow{2}{*}{ All Topics } & \begin{tabular}{|l|} 
Cadbury \\
Schweppes \\
\end{tabular} & 36 & 10 & 10 & 11 & 3 & 3 & 5 & 1 & $\mathbf{0}$ & 21 & $\mathbf{0}$ & $\mathbf{0}$ \\
\hline & & Food sector & 40 & 10 & 9 & 15 & 3 & 3 & 3 & 1 & 0 & 15 & 0 & 1 \\
\hline
\end{tabular}

Type codes $^{1}$ - Description

H - Historical, NTS - Non-time specific, FL - Forward-looking

NF - Non-financial, F - Financial

NQ - Non-quantitative, Q - Quantitative 
Table 5: Pearson Correlations between Proxies for Amount and Spread Dimensions of Disclosure Quality

\begin{tabular}{|c|c|c|c|c|}
\hline & StdRes & MainH & SubH & NonEmp \\
\hline StdRes & 1.00 & 0.311 & -0.426 & 0.464 \\
& & $(0.352)$ & $(0.192)$ & $(0.151)$ \\
\hline MainH & & 1.00 & 0.238 & -0.285 \\
& & & $(0.480)$ & $(0.396)$ \\
\hline SubH & & & 1.00 & -0.689 \\
& & & & $(0.019)^{* *}$ \\
\hline NonEmp & & & & 1.00 \\
\hline
\end{tabular}

Notes to table:

1. Variable definitions:

StdRes $=$ standardised residuals from the regression of TU on MKTCAP and SEG

MainH $=$ Herfindahl index for 9 main topics

$\mathrm{SubH}=$ Herfindahl index for 79 sub-topics

NonEmp $=$ number of non-empty sub-topics.

2. Figures shown below in parentheses give probabilities.

3. ** Significant at 5\% level. 
Table 6: Composite Quality Index and Individual Component Scores

\begin{tabular}{|l|c|c|c|c|c|c|}
\hline \multicolumn{1}{|c|}{ Company } & StdRes & RStdMainH & RStdSubH & StdNonEmp & $\mathbf{Q}_{\mathbf{c}}$ & Rank $\mathbf{Q}_{\mathbf{c}}$ \\
\hline Cadbury Schweppes & 1.198 & 1.947 & 2.114 & 1.579 & 1.710 & 1 \\
\hline Sector mean & 0.0 & 1.0 & 1.0 & 0.0 & 0.500 & \multicolumn{1}{|c}{} \\
\cline { 1 - 5 } Std. deviation & 1.0 & 1.0 & 1.0 & 1.0 & 0.688 & \multicolumn{2}{|c}{}
\end{tabular}

Note to table:

Variable definitions:

StdRes $=$ standardised residuals from the regression of TU on MKTCAP and SEG

RStdMainH $=1-$ standardised Herfindahl index for 9 main topics

RStdSubH $=1$ - standardised Herfindahl index for 79 sub-topics

StdNonEmp $=$ standardised number of non-empty sub-topics. 